\title{
How to Prevent Anastomotic Leak in Colorectal Surgery? A Systematic Review
}

\author{
Mohamed Ali Chaouch ${ }^{1}$, Tarek Kellil ${ }^{1}$, Camillia Jeddi ${ }^{1}$, Ahmed Saidani $^{2}$, Faouzi Chebbi ${ }^{2}$, Khadija Zouari ${ }^{1}$ \\ ${ }^{1}$ Department of Digestive Surgery, Fattouma Bourguiba Hospital, University of Monastir, Monastir; ${ }^{2}$ Department of Digestive Surgery, \\ Mahmoud Matri Hospital, University of Tunis Manar, Tunis, Tunisia
}

\begin{abstract}
Anastomosis leakage (AL) after colorectal surgery is an embarrassing problem. It is associated with poor consequence. This review aims to summarize published evidence on prevention of AL after colorectal surgery and provide recommendations according to the Oxford Centre for Evidence-Based Medicine. We conducted bibliographic research on January 15, 2020, of PubMed, Cochrane Library, Embase, Scopus, and Google Scholar. We retained meta-analysis, reviews, and randomized clinical trials. We concluded that mechanical bowel preparation did not reduce AL. It seems that oral antibiotic or oral antibiotic with mechanical bowel preparation could reduce the risk of AL. The surgical approach did not affect the AL rate. The low ligation of the inferior mesenteric artery could reduce the AL rate. The mechanical anastomosis is superior to handsewn anastomosis only in case of right colectomies, with similar results in rectal surgery between the 2 anastomosis techniques. In the case of right colectomies, this anastomosis could be performed intracorporeally or extracorporeally with similar outcomes. The air leak test did not reduce AL. There is no interest of external drainage in colonic surgery but drains reduced the rate of AL and rate of reoperation after low anterior resection. The transanal tube reduced the rate of AL.
\end{abstract}

Keywords: Anastomotic leak; Colorectal surgery; Prevention \& control; Surgical anastomosis; Complications

\section{INTRODUCTION}

Acute peritonitis following colorectal surgery represents a serious complication with a high mortality incidence, between $6 \%$ and $22 \%[1,2]$. It is essentially secondary to anastomotic leak (AL) in $19 \%$ of cases [3]. Despite the effort in AL comprehension and prevention, its incidence remains stable. The septic complications and prolonged hospitalization induced could lead to a longer hospital stay, delayed adjuvant chemotherapy, or no chemotherapy at all. This could alter oncological outcomes such as cancer recurrence and disease-free survival. However, leakage rates differ from report

Received: Mar 22, 2020 • Revised: May 14, 2020 • Accepted: May 14, 2020 Correspondence to: Mohamed Ali Chaouch, M.D.

Department of Digestive Surgery, Fattouma Bourguiba Hospital, University of Monastir, Farhat Hached Street 5000, Monastir, Tunisia

Tel: +216-26205105, Fax: +216-73460678

E-mail: Docmedalichaouch@gmail.com

ORCID: https://orcid.org/0000-0002-9013-5229

(C) 2020 The Korean Society of Coloproctology

This is an open-access article distributed under the terms of the Creative Commons Attribution NonCommercial License (https://creativecommons.org/licenses/by-nc/4.0) which permits unrestricted noncommercial use, distribution, and reproduction in any medium, provided the original work is properly cited. to report. Such a difference is related to the heterogeneity in how surgeons define anastomotic dehiscence $[4,5]$. Several studies have identified risk factors for this complication despite the lack of consensual definition. The identification of these risk factors, before surgery, constitutes an important step in management, allowing to act on modifiable factors and to adapt the surgical technique. Earlier diagnosis and management could reduce systemic complications but is hindered by current diagnostic methods that are nonspecific and often uninformative. This complication should be suspected in case of any postoperative abnormalities. The management is multidisciplinary and could be present some issues. For that, the best treatment remains prevention of AL.

This review aimed to evaluate the different means of prevention of AL in colorectal surgery, in light of the current literature.

\section{METHODS}

This systematic review was conducted according to PRISMA guidelines [6]. We conducted bibliographic research on January 15, 2020, in the following sources: The National Library of Medicine through PubMed, Cochrane Library, Embase, Scopus, and 
Google Scholar. The keywords used were "anastomotic leakage," "rectal surgery," "colic surgery," "prevention," "anastomosis," "complications," "meta-analysis," "review," and "randomized clinical trial." As concern the inclusion criteria, we retained only metaanalysis, systematic reviews, and randomized clinical trials (RCTs) reporting different modalities of preoperative and intraoperative prevention of AL following colorectal surgery. We performed a restriction of articles published in the English language and including only humans. References of identified articles were searched for additional relevant articles. We excluded from this systematic review controlled clinical trials, case series, case reports, and editorial letters. Articles including AL after a noncolorectal surgery were also excluded from this study. The methodology of the studies that respond to the inclusion criteria was evaluated by 2 authors (TK and MAC), in case of discordance, a discussion was made with KZ. Risk of bias of RCTs was assessed using RobotReviewer [7]. We have excluded all the RCTs which were included in the meta-analysis to avoid redundancy. The strength of clinical data and subsequent recommendations for the prevention of $\mathrm{AL}$ in colorectal surgery were graded according to the Oxford Centre for Evidence-Based Medicine levels of evidence [8] by 2 authors independently, with discrepancies resolved after joint article review and discussion. Levels of evidence are as follows: level 1A, systematic reviews (with homogeneity of RCTs); level $1 \mathrm{~B}$, individual RCTs (with narrow confidence intervals); level 2A, systematic reviews (with homogeneity of cohort studies); and level 2B, individual cohort studies (including low-quality RCTs). Grades of recommendation are as follows: A, consistent level 1 studies; B, consistent level 2 or 3 studies or extrapolations from level 1 studies; $\mathrm{C}$, level 4 studies or extrapolations from level 2 or 3 studies; and D, level 5 evidence or troublingly inconsistent or inconclusive studies of any level.

\section{RESULTS}

\section{Literature research}

After literature research, applying inclusion and exclusion criteria, we have retained 51 articles (Fig. 1) [3, 9-58] published between 2002 and 2020. These articles were distributed as follows: 44 reviews $[3,9-19,21-28,30-35,40-44,46-56]$ including 33 metaanalysis (Table 1) $[10,11,16-19,21,23-28,30,31,33-35,40,42-$ 44, 46-52, 54-56] and 7 RCTs (Table 2) [20, 29, 36-39, 45]. Table 3 summarizes included studies' findings and evidence levels.

\section{Outcomes}

\section{Factors related to the patient}

The predictive factors related to the patient were divided into 2 categories: nonmodifiable factors and modifiable factors. Several reviews [3, 9-15] were interested in identifying these essential factors: male sex [3, 9-14], ASA physical status classification > II [3, $9,11,14]$, alcohol and tobacco use [3,12], associated comorbidities $[3,14,15]$, obesity $[3,11-13]$, malnutrition $[3,9]$, hypoalbu-

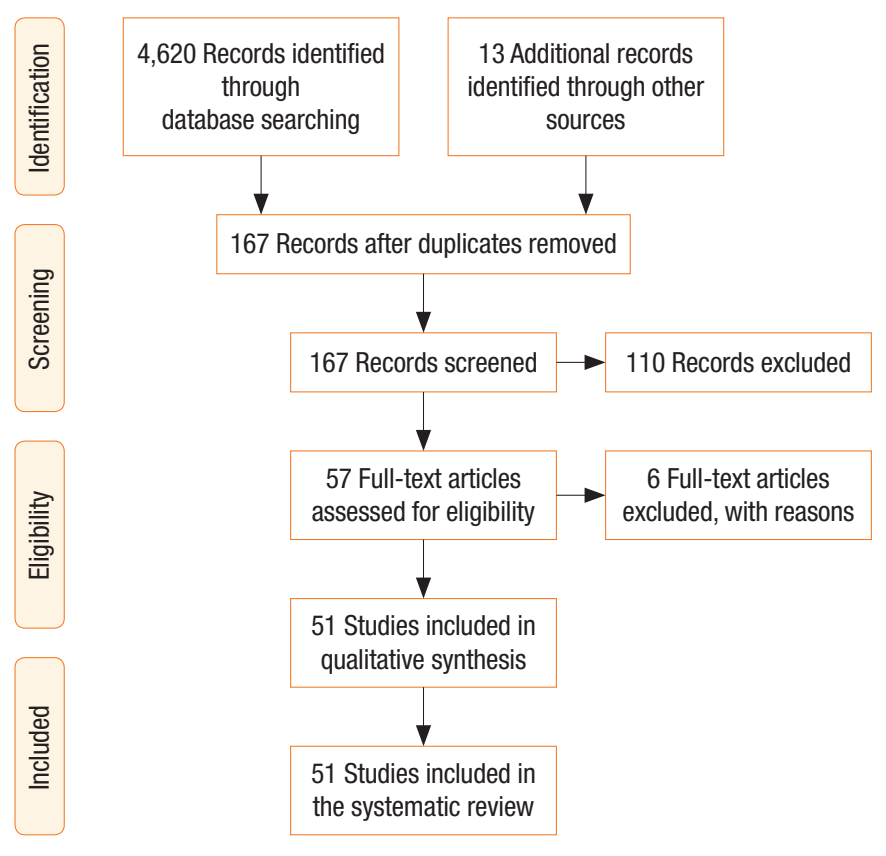

Fig. 1. Flow diagram of the included studies.

min [9], steroid and nonsteroid anti-inflammatory use [3, 9, 14], neoadjuvant radiotherapy $[3,10]$, neoadjuvant chemotherapy [11-13], bevacizumab use $[9,12]$, advanced stage of the tumor $[3$, $11,13]$ the distal localization of rectal tumor [3, 9-11], transfusion [9], and emergent surgery [3, 9].

Colic mechanical preparation and oral antibiotic decontamination The anastomotic contamination by the microbial digestive flora is considered as a major factor contributing to AL. Many means of colic preparation are routinely used to reduce bacterial translocation. Meanwhile, their contribution to the prevention of AL remains uncertain. The impact of the mechanical bowel preparation before the colorectal surgery has been evaluated by the first meta-analysis published by Slim et al. [16] including 7 RCTs (level 1A) which concluded that the mechanical bowel preparation before colorectal surgery significantly increases the AL rate. This study included only small sample trials of which some are not randomized. More recently, in a second meta-analysis [17] including 7 supplementary other randomized trials (level 1A) with 4,859 patients, the same author concluded that there is no significant difference between the group with mechanical bowel preparation and the group without mechanical bowel preparation concerning AL and intraabdominal abscess. These conclusions are confirmed by a Cochrane systematic review (level 1A) published in 2011 [18]. In 2019, in a meta-analysis including 36 studies of which 23 were randomized (level 2A), Rollins et al. [19] concluded also that mechanical bowel preparation before colorectal surgery does not reduce AL rate.

During the last decade, many studies have underlined the im- 
Table 1. Characteristics of the included meta-analysis

\begin{tabular}{|c|c|c|c|c|c|c|c|}
\hline First author & Year & $\begin{array}{l}\text { No. of } \\
\text { studies }\end{array}$ & $\begin{array}{l}\mathrm{RCT} \text { in the } \\
\text { meta-analysis }\end{array}$ & $\begin{array}{c}\text { No. of } \\
\text { patients }\end{array}$ & Population & Intervention & Comparison \\
\hline Pommergaard [10] & 2014 & 11 & 0 & 110,272 & Colorectal cancer & $\begin{array}{l}\text { Age, sex, BMl, low anastomosis, ASA PS } \\
\text { classification, preoperative radiotherapy, tumor stage }\end{array}$ & \\
\hline Qu [11] & 2015 & 14 & 0 & 4,580 & $\begin{array}{l}\text { Laparoscopic } \\
\text { anterior resection }\end{array}$ & $\begin{array}{l}\text { Age, sex, BMI, previous abdominal surgery, ASA PS } \\
\text { classification, albumin, anemia, diabetes, tumor size, } \\
\text { TNM stage, preoperative chemotherapy, operative } \\
\text { time, level of inferior artery ligation, diverting stoma, } \\
\text { intraoperative transfusion, length of first cartridge, } \\
\text { diameter of circular stapler, anastomosis level, pelvic } \\
\text { drain, rectal tube }\end{array}$ & \\
\hline Slim [16] & 2004 & 7 & 7 & 1,454 & $\begin{array}{l}\text { Elective colorectal } \\
\text { surgery }\end{array}$ & Mechanical bowel preparation & No preparation \\
\hline Slim [17] & 2009 & 14 & 14 & 1,859 & $\begin{array}{l}\text { Elective colorectal } \\
\text { surgery }\end{array}$ & Mechanical bowel preparation & No preparation \\
\hline Rollins [21] & 2019 & 40 & 28 & 69,517 & $\begin{array}{l}\text { Elective colorectal } \\
\text { surgery }\end{array}$ & $\begin{array}{l}\text { Mechanical bowel preparation + oral antibiotic } \\
\text { decontamination }\end{array}$ & $\begin{array}{l}\text { Mechanical bowel } \\
\text { preparation }\end{array}$ \\
\hline Ding [23] & 2013 & 12 & 1 & 1,057 & $\begin{array}{l}\text { Right hemicolectomy } \\
\text { for colon cancer }\end{array}$ & Laparoscopic surgery & Open surgery \\
\hline Chaouch [24] & 2019 & 10 & 0 & 2,778 & $\begin{array}{l}\text { Right hemicolectomy } \\
\text { for colon cancer with } \\
\text { complete mesocolon } \\
\text { excision }\end{array}$ & Laparoscopic complete mesocolon excision & $\begin{array}{l}\text { Open complete } \\
\text { mesocolon } \\
\text { excision }\end{array}$ \\
\hline Gavriilidis [25] & 2018 & 8 & 0 & 947 & $\begin{array}{l}\text { Transverse colon } \\
\text { cancer }\end{array}$ & Laparoscopic surgery & Open surgery \\
\hline Neutzling [30] & 2012 & 9 & & 1,233 & $\begin{array}{l}\text { Colorectal } \\
\text { anastomosis }\end{array}$ & Stapled anastomosis & $\begin{array}{l}\text { Hand-sewn } \\
\text { anastomosis }\end{array}$ \\
\hline Choy [31] & 2011 & 7 & 7 & 1,125 & Ileocolic anastomosis & Stapled anastomosis & $\begin{array}{l}\text { Hand-sewn } \\
\text { anastomosis }\end{array}$ \\
\hline Lustosa [33] & 2002 & 9 & 9 & 1,233 & $\begin{array}{l}\text { Colorectal } \\
\text { anastomosis }\end{array}$ & Stapled anastomosis & $\begin{array}{l}\text { Hand-sewn } \\
\text { anastomosis }\end{array}$ \\
\hline van Oostendorp [34] & 2017 & 12 & 1 & 1,492 & Right hemicolectomy & Intracorporeal anastomosis & $\begin{array}{r}\text { Extracorporeal } \\
\text { anastomosis }\end{array}$ \\
\hline Wu [35] & 2017 & 19 & 1 & 1,957 & Right hemicolectomy & Intracorporeal anastomosis & $\begin{array}{r}\text { Extracorporeal } \\
\text { anastomosis }\end{array}$ \\
\hline Wu [40] & 2016 & 12 & 2 & 5,283 & Colorectal surgery & Air leak test & No air leak test \\
\hline Karliczek [42] & 2006 & 6 & 6 & 1,140 & Colorectal surgery & Drain & No drain \\
\hline Rolph [43] & 2004 & 3 & 3 & 908 & Colorectal surgery & Drain & $\begin{array}{l}\text { Placebo (blind ended } \\
\text { drain) or no drain }\end{array}$ \\
\hline Rondelli [44] & 2014 & 8 & 3 & 2,277 & Anterior resection & Drain & No drain \\
\hline
\end{tabular}




\section{Coloproctology

Table 1. Continued

\begin{tabular}{|c|c|c|c|c|c|c|c|}
\hline First author & Year & $\begin{array}{l}\text { No. of } \\
\text { studies }\end{array}$ & $\begin{array}{c}\text { RCT in the } \\
\text { meta-analysis }\end{array}$ & $\begin{array}{c}\text { No. of } \\
\text { patients }\end{array}$ & Population & Intervention & Comparison \\
\hline Hüser [46] & 2008 & 27 & 4 & 15,180 & Low rectal cancer & Diverting stoma & No diverting stoma \\
\hline Montedori [47] & 2010 & 6 & 6 & 648 & Anterior resection & Diverting stoma & No diverting stoma \\
\hline Wu [48] & 2014 & 11 & 3 & 5,612 & Low anterior resection & Diverting stoma & No diverting stoma \\
\hline Gu [49] & 2015 & 13 & 4 & 8,002 & Low anterior resection & Diverting stoma & No diverting stoma \\
\hline Phan [50] & 2019 & 8 & 8 & 892 & Low anterior resection & Diverting stoma & No diverting stoma \\
\hline Gavriilidis [51] & 2019 & 10 & 6 & 1,534 & Colorectal surgery & Loop ileostomy & Loop colostomy \\
\hline Chudner [52] & 2019 & 6 & 2 & 1,063 & Anterior resection & Loop ileostomy & Loop colostomy \\
\hline Wang [54] & 2016 & 4 & 1 & 909 & Anterior resection & Transanal tube & No transanal tube \\
\hline Yang [55] & 2017 & 7 & 2 & 1,772 & Low anterior resection & Transanal tube & No transanal tube \\
\hline Chen [56] & 2018 & 11 & 1 & 2,432 & Anterior resection & Transanal tube & No transanal tube \\
\hline
\end{tabular}

RCT, randomized clinical trial; BMl, body mass index; ASA, American Society of Anesthesiologists; PS, physical status.

Table 2. Characteristics of the included randomized clinical trials

\begin{tabular}{|c|c|c|c|c|c|c|c|c|c|}
\hline First author & Year & Country & $\begin{array}{l}\text { No. of } \\
\text { patients }\end{array}$ & Population & Intervention/comparison & $\begin{array}{c}\text { Random } \\
\text { sequence } \\
\text { generation }\end{array}$ & $\begin{array}{l}\text { Allocation } \\
\text { concealment }\end{array}$ & $\begin{array}{l}\text { Blinding of } \\
\text { participants } \\
\text { and personnel }\end{array}$ & $\begin{array}{l}\text { Blinding of } \\
\text { outcome } \\
\text { assessment }\end{array}$ \\
\hline Sadahiro [20] & 2014 & Japan & 310 & Colon cancer & $\begin{array}{l}\text { Three groups: } \\
\text { (1) probiotics, bifidobacteria-treated group } \\
\text { (group A); (2) oral antibiotics-treated group } \\
\text { (group B); and (3) control group (to which } \\
\text { neither probiotics nor oral antibiotics were } \\
\text { administered) (group C) }\end{array}$ & Low & Low & High/unclear & Low \\
\hline De Nardi [29] & 2020 & Italy & 240 & $\begin{array}{l}\text { Laparoscopic left } \\
\text { sided colon and } \\
\text { rectal resection }\end{array}$ & Indocyanie green angiography & Low & Low & High/unclear & High/unclear \\
\hline Bollo [36] & 2020 & Spain & 140 & $\begin{array}{l}\text { Laparoscopic } \\
\text { right colectomy }\end{array}$ & Intracorporeal/extracorporeal anastomosis & Low & Low & High/unclear & High/unclear \\
\hline Vignali [37] & 2016 & Italy & 60 & $\begin{array}{l}\text { Laparoscopic } \\
\text { right colectomy }\end{array}$ & Intracorporeal/extracorporeal anastomosis & Low & Low & High/unclear & High/unclear \\
\hline Mari [38] & 2018 & Italy & 60 & $\begin{array}{l}\text { Laparoscopic } \\
\text { right colectomy }\end{array}$ & Intracorporeal/extracorporeal anastomosis & Low & Low & High/unclear & Low \\
\hline Allaix [39] & 2019 & Italy & 140 & $\begin{array}{l}\text { Laparoscopic } \\
\text { right colectomy }\end{array}$ & Intracorporeal/extracorporeal anastomosis & Low & Low & High/unclear & Low \\
\hline Denost [45] & 2017 & France & 494 & $\begin{array}{l}\text { Low anterior } \\
\text { resection }\end{array}$ & Drain/no drain & Low & Low & High/unclear & High/unclear \\
\hline
\end{tabular}

portance of oral antibiotics in the reduction of the AL rate. Until now, there are no randomized trials comparing preparation with oral antibiotics versus surgery without preparation. In 2014, in a trial (level 1B) including 310 patients randomized in 3 groups (antibiotic oral decontamination, probiotic use, and control group), Sadahiro et al. [20] demonstrated that oral antibiotic significantly reduced the AL rate in patients following elective surgery for colic cancer $(1 \%, 12 \%$, and $7.4 \%$, respectively). Recently, Rollins et al. [21] concluded that the mechanical bowel preparation associated with oral antibiotic decontamination significantly reduced the AL rate in comparison with a group who had exclusively a mechanical bowel preparation in a meta-analysis including 40 studies of which 28 were randomized (level 2A) with 69,517 patients. Meanwhile, the comparison between mechanical bowel preparations associated with oral antibiotic decontamination versus oral antibiotic decontamination only does not reveal a difference between the 2 groups in terms of AL.

Based on current literature, sufficient evidence does not exist allowing the comparison between mechanical bowel preparation associated with oral antibiotic decontamination versus no prepa- 
Table 3. Recommendations according to the literature findings

\begin{tabular}{|c|c|c|c|}
\hline Feature & $\begin{array}{l}\text { No. of studies by } \\
\text { evidence level }\end{array}$ & Findings $^{\mathrm{a}}$ & $\begin{array}{c}\text { Grade of } \\
\text { recommendation }\end{array}$ \\
\hline Evidence for use of mechanical bowel preparation & $\begin{array}{l}3 \text { level } 1 \text { A studies } \\
1 \text { level } 2 \text { A study }\end{array}$ & No difference & A \\
\hline Evidence for use of oral antibiotic decontamination & $\begin{array}{l}1 \text { level } 1 \text { B study } \\
1 \text { level } 2 \text { A study }\end{array}$ & $\begin{array}{l}\text { Oral antibiotic reduced leak rate } \\
\text { Oral antibiotic with mechanical bowel preparation reduced } \\
\text { anastomotic leak in comparison with mechanical bowel prepara- } \\
\text { tion alone } \\
\text { No difference between oral antibiotic + mechanical preparation } \\
\text { versus oral antibiotic alone }\end{array}$ & - \\
\hline \multirow[t]{3}{*}{$\begin{array}{l}\text { Evidence of the surgical approach: conventional versus } \\
\text { mini-invasive approach }\end{array}$} & 1 level 1 A study & $\begin{array}{l}\text { No difference between surgical approach in anterior resection for } \\
\text { rectal cancer }\end{array}$ & - \\
\hline & 2 level 2 A studies & $\begin{array}{l}\text { No difference between surgical approach in right colectomies for } \\
\text { cancer }\end{array}$ & $\mathrm{B}$ \\
\hline & 1 level 2A study & No difference between surgical approach in transverse colectomies & - \\
\hline $\begin{array}{l}\text { Evidence of the level of inferior mesenteric artery } \\
\text { ligation }\end{array}$ & 1 level 2A study & $\begin{array}{l}\text { Low ligation reduce the rate of anastomotic leak compared to high } \\
\text { ligation with no difference in terms of oncological outcomes }\end{array}$ & - \\
\hline \multicolumn{4}{|l|}{$\begin{array}{l}\text { Evidence of the anastomosis technique: hand sewn } \\
\text { versus stapled anastomosis }\end{array}$} \\
\hline Colorectal surgery & 1 level 1 A study & No difference & - \\
\hline Right colectomies & $\begin{array}{l}1 \text { level } 1 \text { A study } \\
1 \text { level } 2 \text { A study }\end{array}$ & Mechanical anastomosis reduces the rate of anastomosis leak & $\mathrm{B}$ \\
\hline Rectal surgery & 1 level 1 A study & No difference & - \\
\hline $\begin{array}{l}\text { Evidence of the anastomosis technique: intracorporeal } \\
\text { versus extracorporeal ileocolic anastomosis }\end{array}$ & $\begin{array}{l}4 \text { level } 1 B \text { studies } \\
2 \text { level } 2 \text { A studies }\end{array}$ & No difference & A \\
\hline Evidence for use of air leak test & 1 level 2 A study & No difference & - \\
\hline $\begin{array}{l}\text { Evidence for use of external drainage of the abdominal } \\
\text { cavity after colon surgery }\end{array}$ & $\begin{array}{l}1 \text { level } 1 \text { A study } \\
1 \text { level } 2 \text { A study }\end{array}$ & There is no interest in drainage & B \\
\hline $\begin{array}{l}\text { Evidence for use of external drainage of the abdominal } \\
\text { cavity after rectal surgery }\end{array}$ & $\begin{array}{l}1 \text { level } 1 \text { B study } \\
2 \text { level } 2 \text { A studies }\end{array}$ & $\begin{array}{l}\text { No difference } \\
\text { Pelvic drainage reduced the rate of anastomotic leak and the rate of } \\
\text { reoperation }\end{array}$ & $\bar{B}$ \\
\hline $\begin{array}{l}\text { Evidence for use of diverting stoma after low anterior } \\
\text { resection }\end{array}$ & $\begin{array}{l}1 \text { level } 1 \text { A study } \\
4 \text { level } 2 \text { A studies }\end{array}$ & $\begin{array}{l}\text { Diverting stoma reduced the rate of anastomotic leak and the rate } \\
\text { of reoperation }\end{array}$ & B \\
\hline Evidence for use of transanal tube & $\begin{array}{l}2 \text { level } 2 \text { A studies } \\
1 \text { level } 2 \text { A study }\end{array}$ & $\begin{array}{l}\text { Transanal tube reduced the rate of anastomotic leak and the rate of } \\
\text { reoperation } \\
\text { Transanal tube reduced the rate of anastomotic leak even in pa- } \\
\text { tients with ostomy }\end{array}$ & B \\
\hline
\end{tabular}

a Levels of evidence are as follows: level 1A, systematic reviews (with homogeneity of randomized clinical trials [RCTs]); level 1B, individual RCTs (with narrow confidence intervals); level 2A, systematic reviews (with homogeneity of cohort studies); and level 2B, individual cohort studies (including low-quality RCTs). '⿳⺈⿴囗十 tion are as follows: A, consistent level 1 studies; B, consistent level 2 or 3 studies or extrapolations from level 1 studies; C, level 4 studies or extrapolations from level 2 or 3 studies; and D, level 5 evidence or troublingly inconsistent or inconclusive studies of any level.

ration; oral antibiotic decontamination versus no preparation and oral antibiotic preparation versus mechanical bowel preparation.

\section{Factors related to anesthesia}

It is commonly admitted that cooperation between surgeons and anesthesiologist improves postoperative outcomes following colorectal surgery. Many intraoperative factors related to anesthesia were suspected to be risk factors of AL. In a systematic review published in 2015, Vasiliu et al. [9] concluded that intraoperative transfusion increases the risk of AL. In 2016, Van Rooijen et al. [22] have con- firmed this finding. This author otherwise reported many other factors (multimodal analgesia, optimal intraoperative perfusion, use of vasoactive drogues, and oxygen therapy) that improve early postoperative outcomes, without any influence on the rate of AL.

\section{Surgical approach: conventional versus mini-invasive approach}

Since its first description in 1991, the mini-invasive approach has steadily progressed to currently become the gold standard for colectomies in case of benign and malignant diseases.

Two meta-analyses (level 2A) [23, 24] have compared the lapa- 
roscopic approach to conventional approach during right hemicolectomies for cancer. These meta-analyses have not demonstrated differences in terms of an AL between both approaches. Another meta-analysis (level 2A) [25] comparing the laparoscopic and the conventional approaches for transverse colectomies have not demonstrated any difference in terms of an AL between both approaches. Otherwise, neither meta-analysis nor RCTs are comparing both approaches for left colectomies in terms of AL. Concerning rectal surgery, the laparoscopic approach would be associated with a higher theoretical risk of AL, essentially in obese patients [57]. This is associated with the difficulty of the section using instruments with limited angulations and a confection of an anastomosis in a narrow space.

A meta-analysis of randomized trials (level 1A) published in 2019 [26] compared the different approaches in anterior resection for rectal cancer. Twenty-nine randomized trials were included. The authors concluded that the approach does not affect the AL rate.

\section{High versus low inferior mesenteric artery ligation}

Despite the multifactorial causes, the perfusion disorder and technical defects are considered as major factors of anastomotic dehiscence. The level of vascular ligation could, therefore, affect in some patients the blood flow at the level of the anastomosis and hinder its healing. This problem rises especially for tumors of the sigmoid colon and rectum, where the high ligation of the inferior mesenteric artery can impede vascularization of the proximal end of the anastomosis.

Si et al. [27] compared high versus low inferior mesenteric artery ligation in case of sigmoid or rectal cancer in a meta-analysis published in 2019 including 30 studies (level 2A), which 6 out of them were randomized. The conclusion was in favor of low ligation in terms of preventing anastomotic dehiscence. There was no difference in term of oncological outcomes (total number of lymph nodes retrieved, local recurrence, overall survival at 5 years, and survival without recurrence at 5 years). Since the appearance of the concept of image-guided surgery, several studies have evaluated the interest of fluorescence during colorectal surgery. Indocyanine green represents the most sophisticated technique and would allow an operative assessment of the quality of the vascular supply of the anastomosis. A meta-analysis published in 2018 by Shen et al. [28], including 4 controlled clinical trials (level 2A) with 1,177 patients, concluded that the use of Indocyanine green allows to significantly reduce the rate of AL. However, there was a heterogeneity observed between the different studies. In this report, the fluorescence contributed to the modification of the surgical technique in $4.7 \%$ to $16.4 \%$ of the cases $[58,59]$ and allowed to extend the resection margins in 19\% of patients [60]. However, these results were not confirmed by a multicenter randomized study (level 1B) published by De Nardi et al. [29] in 2020. This study included 240 patients. The authors concluded fluorescence extended resection margin in 13 patients (11\%) but did not significantly reduce the rate of AL.

\section{Anastomosis technique \\ Hand sewn versus stapled anastomosis}

A meta-analysis of RCTs (level 1A) [30] including 1,233 patients and comparing stapled and hand-sewn anastomosis for colorectal surgery concluded that there was no difference in terms of a radiological and clinical AL between the 2 techniques. However, this meta-analysis did not compare each colorectal segments separately which represent a judgment bias related to the difference in vascularization, the difference in the diameter of the intestinal lumen and the difference in the reconstruction technique between ilio-colic, colo-colic, colorectal anastomosis, and after colostomy closure. A meta-analysis published by Cochrane Library [31] including 7 trials (level 1A) compared 441 patients with stapled ilio-colic anastomosis with 684 patients with hand-sewn anastomosis. Although there was no difference reported by each of the studies in terms of an AL between the 2 techniques, the combined analysis was in favor of the mechanical anastomosis. These results were confirmed by a recent meta-analysis (level 2A) published in 2019 by Luglio and Corcione [32] the widespread of a circular stapler in recent years has meant that many patients who would have had amputation may currently benefit from anterior resection. A meta-analysis of randomized trials (level 1A) [33] published in 2002 did not show any difference in terms of $\mathrm{AL}$, but stapled anastomosis shortened operating time and were useful in laparoscopic surgery. That is why most anastomosis is done by mechanical anastomosis nowadays.

\section{Intracorporal versus extracorporal anastomosis}

This comparison represents a subject of debate, especially after iliocolectomy. Two meta-analyses (level 2A) published in 2016 and $2017[34,35]$ compared the 2 techniques in terms of AL. The authors did not find a difference in favor of one of the 2 techniques. These results were consistent with 4 randomized trials published later (level 1B) [36-39].

\section{Intraoperative tests to verify the anastomosis}

The verification of the tightness of the anastomosis is crucial during the operation. There are 2 ways to isolate anastomosis with risk: air leak test and intraoperative endoscopy. Identifying these at-risk patients would allow for additional preventive measures such a repairing the anastomosis with stitches or making a diverting stoma.

A meta-analysis published by Wu et al. [40] in 2016 (including 20 studies, 2 of which are randomized [level 2A]) evaluated the effectiveness of the colorectal anastomosis air leak test at the end of the intervention. These authors concluded that this procedure did not decrease the risk of an AL but identified patients at high risk of a leak in whom prevention measures are necessary. The use of intraoperative endoscopy allows direct visualization of a defect or bleeding at the level of the anastomosis, iatrogenic lesion of the anastomotic rectal wall, the quality of the vascularization of the anastomosis and the detection of a possible lesion which was 
not detected in the preoperative assessment [41]. However, this procedure must be conducted by an endoscopic expert [41].

\section{External drainage of the abdominal cavity}

The use of intraabdominal drain in colorectal surgery has been widely debated in terms of early detection of complication and in terms of preventing anastomotic dehiscence. The current literature, according to 2 meta-analyses (level $1 \mathrm{~A}$ and $2 \mathrm{~A}$ ), concluded with a high level of evidence that there is no longer any interest in a drainage after colon surgery [42, 43]. However, the external drainage of the abdominal cavity after anterior resection remains a subject of controversy.

After total mesorectal excision, the space left would promote the development of hematoma and seroma; factors favoring bacterial proliferation. The translocation of bacteria at the site of the anastomosis would cause an AL.

In 2014, Rondelli et al. [44] showed that pelvic drainage reduced the rate of anastomotic dehiscence and the rate reoperation in patients who had anterior resection with extraperitoneal anastomosis in a systematic review and meta-analysis including 3 randomized studies and 2,277 patients (level 2A). These conclusions were confirmed by a second meta-analysis (level 2A) in 2015 [11]. However, a recent randomized trial (level 1B) lead by Denost et al. [45] including 469 patients who had an anterior resection with an extraperitoneal anastomosis showed that there was no significant difference in terms of pelvic sepsis between the group of patients who had external abdominal drainage and the group of patients without drainage. Furthermore, there was no difference in terms of pelvic sepsis between early removal (less than 5 days) and late removal (more than 5 days).

\section{Diverting stoma \\ Diverting stoma versus no stoma}

Since its description by Heald [61], the total mesorectal excision increased the rate of sphincter preservation in the case of lower rectal cancer. However, this procedure presents Achilles heel which is the symptomatic AL.

Based on old literature, some factors related to the general condition of the patient, the low location of the tumor and the pelvic measurements are indications for performing diverting stoma. This procedure would reduce the risk of AL, and in case of occurrence the severity of septic complication related to this leak. This role has been confirmed by several meta-analyses (level 2A) [4649] of which one (level 1A) published in 2019 [50] including 8 randomized trials and 892 patients. In this meta-analysis, Phan et al. [50] concluded that the diverting stoma significantly reduced the rate of $\mathrm{AL}$ and the rate of reoperation after anterior resection for low rectal cancer.

Regarding the choice of the type of ostomy (ileostomy or colostomy) opinions remain controversial. In a meta-analysis published in 2019 by including 10 studies (level 2A) and 1,534 patients, Gavriilidis et al. [51] compared ileostomy to transverse co- lostomy in colorectal surgery. This study found a higher rate of stoma prolapsed after a colostomy. Following the restoration of digestive continuity, there were more wound infections and incisional hernias in patients who had a colostomy. On the other hand, an ileostomy was correlated with a higher complication rate related to high stoma flow. Regarding the over mobility after the stoma was made or closed there was no superiority of 1 of the 2 procedures; however, the heterogeneity between the different studies included in this meta-analysis was high. Taking into account anterior resection only, a systematic review and meta-analysis (level 2A) [52] compared ileostomy and colostomy in terms of postoperative morbidity. Chudner et al. [52] included 2 randomized trials and 1,063 patients and concluded that the overall morbidity (after making and closing the stoma) was not different between these 2 techniques.

\section{Virtual (ghost) stoma}

Based on current literature, the role of diverting stoma in patients at high risk of AL does not need to be demonstrated. However, this procedure exposes patients to local and general complications prompting some authors to propose virtual stoma.

The interest of virtual stoma was recently evaluated by Baloyiannis et al. [53] (level 2A) who concluded that this procedure presents a safe and feasible alternative that can replace the diverting stoma. Meanwhile, it does not reduce the risk of anastomotic dehiscence; the rate of $\mathrm{AL}$ and conversion to ostomy was $11.9 \%$ and $10.46 \%$, respectively.

\section{Transanal tube}

The use of transanastomotic tube has been suggested as a means to reduce the risk of anastomotic fistulas in patients who have had an anterior resection with a low level of anastomosis. On the other hand, this procedure would avoid complications related to diverting stoma.

Wang et al. [54] in a meta-analysis (level 2A) including 909 patients who had an anterior resection showed that the placement of a transanal tube reduces the risk of $\mathrm{AL}$ and reoperation related to this complication. Similar results have been reported by another more recent meta-analysis (level 2A) [55] including 1,772 patients, there was no difference reported in terms of anastomotic bleeding and mortality between the 2 groups with and without a transanal tube.

Another meta-analysis (level 2A) published by Chen et al. [56], including patients who had anterior resection with or without diverting stoma, concluded that transanal tube placement significantly reduced the risk of anastomotic dehiscence even in patients with an ostomy.

In conclusion, decompression through transanal tube could be a means of preventing AL in high-risk patients. It could replace the diverting stoma, avoiding complications related to this procedure. However, randomized studies comparing the 2 techniques are necessary. 


\section{CONCLUSION}

Despite the advances in surgical procedures, the rate of AL following colorectal surgery remains high. Prevention of this complication represents a huge challenge. We have tried to identify with a high level of evidence, mainly coming from reviews and RCTs, the risk factors and measures to reduce this complication and subsequent effects. Several modifiable and nonmodifiable factors have been extensively investigated. There was unanimity in the involvement of some of these factors in the genesis of anastomotic fistulas. However, others are still a subject of controversy. This underlines that the pathogenesis of AL is multifactorial and other potential factors remain unexplored.

\section{CONFLICT OF INTEREST}

No potential conflict of interest relevant to this article was reported.

\section{REFERENCES}

1. Rullier E, Laurent C, Garrelon JL, Michel P, Saric J, Parneix M. Risk factors for anastomotic leakage after resection of rectal cancer. Br J Surg 1998;85:355-8.

2. Hyman N, Manchester TL, Osler T, Burns B, Cataldo PA. Anastomotic leaks after intestinal anastomosis: it's later than you think. Ann Surg 2007;245:254-8.

3. McDermott FD, Heeney A, Kelly ME, Steele RJ, Carlson GL, Winter DC. Systematic review of preoperative, intraoperative and postoperative risk factors for colorectal anastomotic leaks. $\mathrm{Br} \mathrm{J}$ Surg 2015;102:462-79.

4. Daniel VT, Alavi K, Davids JS, Sturrock PR, Harnsberger CR, Steele SR, et al. The utility of the Delphi method in defining anastomotic leak following colorectal surgery. Am J Surg 2020;219:759.

5. Guyton KL, Hyman NH, Alverdy JC. Prevention of perioperative anastomotic healing complications: anastomotic stricture and anastomotic leak. Adv Surg 2016;50:129-41.

6. Moher D, Liberati A, Tetzlaff J, Altman DG; PRISMA Group. Preferred reporting items for systematic reviews and meta-analyses: the PRISMA statement. Int J Surg 2010;8:336-41.

7. Marshall IJ, Kuiper J, Wallace BC. RobotReviewer: evaluation of a system for automatically assessing bias in clinical trials. J Am Med Inform Assoc 2016;23:193-201.

8. Centre for Evidence-Based Medicine. Oxford Centre for Evidencebased Medicine - levels of evidence (March 2009) [Internet]. Oxford (UK): Centre for Evidence-Based Medicine; 2009 [cited 2019 Feb 3]. Available from: https://www.cebm.net/2009/06/oxfordcentre-evidence-based-medicine-levels-evidence-march-2009/

9. Vasiliu EC, Zarnescu NO, Costea R, Neagu S. Review of risk factors for anastomotic leakage in colorectal surgery. Chirurgia $(\mathrm{Bu}-$ cur) 2015;110:319-26.
10. Pommergaard HC, Gessler B, Burcharth J, Angenete E, Haglind E, Rosenberg J. Preoperative risk factors for anastomotic leakage after resection for colorectal cancer: a systematic review and metaanalysis. Colorectal Dis 2014;16:662-71.

11. Qu H, Liu Y, Bi DS. Clinical risk factors for anastomotic leakage after laparoscopic anterior resection for rectal cancer: a systematic review and meta-analysis. Surg Endosc 2015;29:3608-17.

12. Kawada K, Sakai Y. Preoperative, intraoperative and postoperative risk factors for anastomotic leakage after laparoscopic low anterior resection with double stapling technique anastomosis. World J Gastroenterol 2016;22:5718-27.

13. Sciuto A, Merola G, De Palma GD, Sodo M, Pirozzi F, Bracale UM, et al. Predictive factors for anastomotic leakage after laparoscopic colorectal surgery. World J Gastroenterol 2018;24:2247-60.

14. Fujita F, Torashima Y, Kuroki T, Eguchi S. Risk factors and predictive factors for anastomotic leakage after resection for colorectal cancer: reappraisal of the literature. Surg Today 2014;44:1595602 .

15. Stergios K, Kontzoglou K, Pergialiotis V, Korou LM, Frountzas M, Lalude $\mathrm{O}$, et al. The potential effect of biological sealants on colorectal anastomosis healing in experimental research involving severe diabetes. Ann R Coll Surg Engl 2017;99:189-92.

16. Slim K, Vicaut E, Panis Y, Chipponi J. Meta-analysis of randomized clinical trials of colorectal surgery with or without mechanical bowel preparation. Br J Surg 2004;91:1125-30.

17. Slim K, Vicaut E, Launay-Savary MV, Contant C, Chipponi J. Updated systematic review and meta-analysis of randomized clinical trials on the role of mechanical bowel preparation before colorectal surgery. Ann Surg 2009;249:203-9.

18. Güenaga KF, Matos D, Wille-Jørgensen P. Mechanical bowel preparation for elective colorectal surgery. Cochrane Database Syst Rev 2011;2011:CD001544.

19. Rollins KE, Javanmard-Emamghissi H, Lobo DN. Impact of mechanical bowel preparation in elective colorectal surgery: a metaanalysis. World J Gastroenterol 2018;24:519-36.

20. Sadahiro S, Suzuki T, Tanaka A, Okada K, Kamata H, Ozaki T, et al. Comparison between oral antibiotics and probiotics as bowel preparation for elective colon cancer surgery to prevent infection: prospective randomized trial. Surgery 2014;155:493-503.

21. Rollins KE, Javanmard-Emamghissi H, Acheson AG, Lobo DN. The role of oral antibiotic preparation in elective colorectal surgery: a meta-analysis. Ann Surg 2019;270:43-58.

22. Van Rooijen SJ, Huisman D, Stuijvenberg M, Stens J, Roumen $\mathrm{RMH}$, Daams F, et al. Intraoperative modifiable risk factors of colorectal anastomotic leakage: why surgeons and anesthesiologists should act together. Int J Surg 2016;36(Pt A):183-200.

23. Ding J, Liao GQ, Xia Y, Zhang ZM, Liu S, Yan ZS. Laparoscopic versus open right hemicolectomy for colon cancer: a meta-analysis. J Laparoendosc Adv Surg Tech A 2013;23:8-16.

24. Chaouch MA, Dougaz MW, Bouasker I, Jerraya H, Ghariani W, Khalfallah M, et al. Laparoscopic versus open complete mesocolon excision in right colon cancer: a systematic review and meta- 
analysis. World J Surg 2019;43:3179-90.

25. Gavriilidis P, Katsanos K. Laparoscopic versus open transverse colectomy: a systematic review and meta-analysis. World J Surg 2018;42:3008-14.

26. Simillis C, Lal N, Thoukididou SN, Kontovounisios C, Smith JJ, Hompes R, et al. Open versus laparoscopic versus robotic versus transanal mesorectal excision for rectal cancer: a systematic review and network meta-analysis. Ann Surg 2019;270:59-68.

27. Si MB, Yan PJ, Du ZY, Li LY, Tian HW, Jiang WJ, et al. Lymph node yield, survival benefit, and safety of high and low ligation of the inferior mesenteric artery in colorectal cancer surgery: a systematic review and meta-analysis. Int J Colorectal Dis 2019;34:94762.

28. Shen R, Zhang Y, Wang T. Indocyanine green fluorescence angiography and the incidence of anastomotic leak after colorectal resection for colorectal cancer: a meta-analysis. Dis Colon Rectum 2018;61:1228-34.

29. De Nardi P, Elmore U, Maggi G, Maggiore R, Boni L, Cassinotti E, et al. Intraoperative angiography with indocyanine green to assess anastomosis perfusion in patients undergoing laparoscopic colorectal resection: results of a multicenter randomized controlled trial. Surg Endosc 2020;34:53-60.

30. Neutzling CB, Lustosa SA, Proenca IM, da Silva EM, Matos D. Stapled versus handsewn methods for colorectal anastomosis surgery. Cochrane Database Syst Rev 2012;(2):CD003144.

31. Choy PY, Bissett IP, Docherty JG, Parry BR, Merrie A, Fitzgerald A. Stapled versus handsewn methods for ileocolic anastomoses. Cochrane Database Syst Rev 2011;(9):CD004320.

32. Luglio G, Corcione F. Stapled versus handsewn methods for ileocolic anastomoses. Tech Coloproctol 2019;23:1093-5.

33. Lustosa SA, Matos D, Atallah AN, Castro AA. Stapled versus handsewn methods for colorectal anastomosis surgery: a systematic review of randomized controlled trials. Sao Paulo Med J 2002;120:132-6.

34. van Oostendorp S, Elfrink A, Borstlap W, Schoonmade L, Sietses C, Meijerink J, et al. Intracorporeal versus extracorporeal anastomosis in right hemicolectomy: a systematic review and metaanalysis. Surg Endosc 2017;31:64-77.

35. Wu Q, Jin C, Hu T, Wei M, Wang Z. Intracorporeal versus extracorporeal anastomosis in laparoscopic right colectomy: a systematic review and meta-analysis. J Laparoendosc Adv Surg Tech A 2017;27:348-57.

36. Bollo J, Turrado V, Rabal A, Carrillo E, Gich I, Martinez MC, et al. Randomized clinical trial of intracorporeal versus extracorporeal anastomosis in laparoscopic right colectomy (IEA trial). Br J Surg 2020;107:364-72.

37. Vignali A, Bissolati M, De Nardi P, Di Palo S, Staudacher C. Extracorporeal vs. intracorporeal ileocolic stapled anastomoses in laparoscopic right colectomy: an interim analysis of a randomized clinical trial. J Laparoendosc Adv Surg Tech A 2016;26:3438.

38. Mari GM, Crippa J, Costanzi AT, Pellegrino R, Siracusa C, Berar- di V, et al. Intracorporeal anastomosis reduces surgical stress response in laparoscopic right hemicolectomy: a prospective randomized trial. Surg Laparosc Endosc Percutan Tech 2018;28:7781 .

39. Allaix ME, Degiuli M, Bonino MA, Arezzo A, Mistrangelo M, Passera R, et al. Intracorporeal or extracorporeal ileocolic anastomosis after laparoscopic right colectomy: a double-blinded randomized controlled trial. Ann Surg 2019;270:762-7.

40. Wu Z, van de Haar RC, Sparreboom CL, Boersema GS, Li Z, Ji J, et al. Is the intraoperative air leak test effective in the prevention of colorectal anastomotic leakage?: a systematic review and metaanalysis. Int J Colorectal Dis 2016;31:1409-17.

41. Liu ZH, Liu JW, Chan FS, Li MK, Fan JK. Intraoperative colonoscopy in laparoscopic colorectal surgery: a review of recent publications. Asian J Endosc Surg 2020;13:19-24.

42. Karliczek A, Jesus EC, Matos D, Castro AA, Atallah AN, Wiggers T. Drainage or nondrainage in elective colorectal anastomosis: a systematic review and meta-analysis. Colorectal Dis 2006;8:25965.

43. Rolph R, Duffy JM, Alagaratnam S, Ng P, Novell R. Intra--abdominal drains for the prophylaxis of anastomotic leak in elective colorectal surgery. Cochrane Database Syst Rev 2004;(4):CD002100.

44. Rondelli F, Bugiantella W, Vedovati MC, Balzarotti R, Avenia N, Mariani E, et al. To drain or not to drain extraperitoneal colorectal anastomosis?: a systematic review and meta-analysis. Colorectal Dis 2014;16:O35-42.

45. Denost Q, Rouanet P, Faucheron JL, Panis Y, Meunier B, Cotte E, et al. To drain or not to drain infraperitoneal anastomosis after rectal excision for cancer: the GRECCAR 5 randomized trial. Ann Surg 2017;265:474-80.

46. Hüser N, Michalski CW, Erkan M, Schuster T, Rosenberg R, Kleeff J, et al. Systematic review and meta-analysis of the role of defunctioning stoma in low rectal cancer surgery. Ann Surg 2008; 248:52-60.

47. Montedori A, Cirocchi R, Farinella E, Sciannameo F, Abraha I. Covering ileo- or colostomy in anterior resection for rectal carcinoma. Cochrane Database Syst Rev 2010;(5):CD006878.

48. Wu SW, Ma CC, Yang Y. Role of protective stoma in low anterior resection for rectal cancer: a meta-analysis. World J Gastroenterol 2014;20:18031-7.

49. Gu WL, Wu SW. Meta-analysis of defunctioning stoma in low anterior resection with total mesorectal excision for rectal cancer: evidence based on thirteen studies. World J Surg Oncol 2015;13:9.

50. Phan K, Oh L, Ctercteko G, Pathma-Nathan N, El Khoury T, Azam $\mathrm{H}$, et al. Does a stoma reduce the risk of anastomotic leak and need for re-operation following low anterior resection for rectal cancer: systematic review and meta-analysis of randomized controlled trials. J Gastrointest Oncol 2019;10:179-87.

51. Gavriilidis P, Azoulay D, Taflampas P. Loop transverse colostomy versus loop ileostomy for defunctioning of colorectal anastomosis: a systematic review, updated conventional meta-analysis, and cumulative meta-analysis. Surg Today 2019;49:108-17. 


\section{Coloproctology Mohamed Ali Chaouch, et al.}

52. Chudner A, Gachabayov M, Dyatlov A, Lee H, Essani R, Bergamaschi R. The influence of diverting loop ileostomy vs. colostomy on postoperative morbidity in restorative anterior resection for rectal cancer: a systematic review and meta-analysis. Langenbecks Arch Surg 2019;404:129-39.

53. Baloyiannis I, Perivoliotis K, Diamantis A, Tzovaras G. Virtual ileostomy in elective colorectal surgery: a systematic review of the literature. Tech Coloproctol 2020;24:23-31.

54. Wang S, Zhang Z, Liu M, Li S, Jiang C. Efficacy of transanal tube placement after anterior resection for rectal cancer: a systematic review and meta-analysis. World J Surg Oncol 2016;14:92.

55. Yang Y, Shu Y, Su F, Xia L, Duan B, Wu X. Prophylactic transanal decompression tube versus non-prophylactic transanal decompression tube for anastomotic leakage prevention in low anterior resection for rectal cancer: a meta-analysis. Surg Endosc 2017;31: 1513-23.

56. Chen H, Cai HK, Tang YH. An updated meta-analysis of transanal drainage tube for prevention of anastomotic leak in anterior resection for rectal cancer. Surg Oncol 2018;27:333-40.

57. Scheidbach H, Benedix F, Hugel O, Kose D, Kockerling F, Lippert H. Laparoscopic approach to colorectal procedures in the obese patient: risk factor or benefit? Obes Surg 2008;18:66-70.

58. Kudszus S, Roesel C, Schachtrupp A, Hoer JJ. Intraoperative laser fluorescence angiography in colorectal surgery: a noninvasive analysis to reduce the rate of anastomotic leakage. Langenbecks Arch Surg 2010;395:1025-30.

59. Boni L, Fingerhut A, Marzorati A, Rausei S, Dionigi G, Cassinotti E. Indocyanine green fluorescence angiography during laparoscopic low anterior resection: results of a case-matched study. Surg Endosc 2017;31:1836-40.

60. Jafari MD, Lee KH, Halabi WJ, Mills SD, Carmichael JC, Stamos $\mathrm{MJ}$, et al. The use of indocyanine green fluorescence to assess anastomotic perfusion during robotic assisted laparoscopic rectal surgery. Surg Endosc 2013;27:3003-8.

61. Heald RJ. A new approach to rectal cancer. Br J Hosp Med 1979; 22:277-81. 